\title{
UTILIZATION OF SELENIUM COMPOUNDS IN NUTRITION OF LAMBS
}

\author{
Maja Słupczyńska, Stefania Kinal, Monika Hadryś, \\ Barbara Król \\ Chair of Animal Nutrition and Feed Science \\ Wroclaw University of Environmental and Life Sciences
}

\begin{abstract}
The level of mineral utilization depends on many factors related to animals as well as to the chemical form of given nutrients. It has been experimentally demonstrated that animals utilize inorganic forms of minerals less efficiently than organic ones. Hence, an attempt has been made to evaluate the bioavailability of selenium bound in different compounds to lambs. Selenium supplementation in fodder mixtures was another aspect included in our tests. Thus, an experiment was conducted on 48 growing lambs, testing the level and chemical forms of selenium in fodder mixtures for animals. In group I (the control) lambs received fodder mixture without any selenium supplement. In the experimental groups, selenium was supplemented as sodium selenite in the amount $0.2 \mathrm{mg} \mathrm{Se} \mathrm{kg}^{-1}$ d.m. feeds (II), or selenium enriched yeast (Se-yeast) in the amounts of 0.1 and $0.2 \mathrm{mg}$ Se kg-1 d.m. of feed groups III and IV, respectively. At the end of the experiment, when animals had reached 35 kilos of weight, blood samples were taken. The activity of glutathione peroxidase was estimated in heparinized blood samples. Eight lambs were chosen from each group and killed to collect samples of soft tissues (liver, kidney, brain, muscle). The content of selenium was determined in the tissue samples. Supplementation of feeds for lambs with selenium, both inorganic (sodium selenite) and organic (Se-yeast), increased the content of the element in soft tissues of animals. The highest level of the element was found in the liver and kidneys: 4.65 and 4.90 and 2.10 and $2.30 \mathrm{mg} \mathrm{kg}^{-1}$ fresh tissue, of the lambs receiving sodium selenine and Se-yeast in the amount $0.2 \mathrm{mg} \mathrm{Se} \mathrm{kg}^{-1}$ D.M. of feed (groups II and IV), respectively. Selenium compounds added to feeds given to lambs significantly (PŁ0.01) increased activity of GSH-Px in blood, especially in the case of animals which received yeast enriched with selenium. In blood of the lambs which received feeds with Se-yeast in the amount $0.2 \mathrm{mg} \mathrm{Se} \mathrm{kg}^{-1} \mathrm{~d} . \mathrm{m}$. of feed (group IV), the activity of glutathione peroxidase was by $129.71 \mathrm{U} \mathrm{gHb}^{-1}$ higher, and of the animals which received Se-yeast in the amount $0.1 \mathrm{mg} \mathrm{kg}^{-1} \mathrm{~d} . \mathrm{m}$. or sodium selenite, the activity of the enzyme was higher by 86.33 and $86.35 \mathrm{U} \mathrm{gHb}^{-1}$, respectively, than the activity of this enzyme in blood of animals from the control group. Supplementation of lambs' rations with Se in
\end{abstract}

dr Maja Słupczyńska, Chair of Animal Nutrition and Feed Science, Wroclaw University of Environmental and Life Sciences, Chelmonskiego 38C, 51-630 Wroclaw 
the form of selenite or yeast enriched with selenium forms increased the content of Se in soft tissues and gluthatione peroxidase activity in comparison with animals which did not receive additional doses of this nutrient in fodder mixtures. The availability of Se was more profoundly affected by the amount of the element added rather than its form.

Key words: bioavailability, selenium, tissue accumulation, glutathione peroxidase.

\title{
WYKORZYSTANIE ZWIĄZKÓW SELENU W ŻYWIENIU JAGNIĄT
}

\begin{abstract}
Abstrakt
Stopień wykorzystania składników mineralnych z paszy zależy od wielu czynników związanych zarówno ze zwierzęciem, jak i z formą chemiczna stosowanych związków. W badaniach wskazano, że związki nieorganiczne są najczęściej gorzej wykorzystywane niż ich organiczne odpowiedniki. Dlatego podjęto próbę oceny przyswajalności przez jagnięta różnych związków selenu, uwzględniając także poziom dodatku tego pierwiastka w mieszankach. W badaniach na 48 rosnących jagniętach czynnikiem różnicującym poszczególne grupy były różne poziomy i formy połączeń chemicznych selenu w mieszankach treściwych. W grupie I (kontrolnej) jagnięta otrzymywały mieszankę bez dodatku selenu. W grupach (II) doświadczalnych mieszanki uzupełniano seleninem sodu w ilości $0.2 \mathrm{mg}$ Se kg-1 s.m. paszy, a w grupach III i IV - drożdżami wzbogaconymi w selen (drożdże-Se), odpowiednio w ilości: 0.1 i $0.2 \mathrm{mg}$ Se kg-1 $\mathrm{s}$ s.m. paszy. Na końcu doświadczenia, po osiagnięciu przez zwierzęta masy ciała ok. $35 \mathrm{~kg}$, pobrano od nich krew. Następnie w pełnej heparynizowanej krwi oznaczono aktywność peroksydazy glutationowej (GSH-Px). Z każdej grupy wybrano losowo po 8 jagniąt, zwierzęta ubito i pobrano tkanki miękkie (wątroba, nerki, mózg, mięsień przywodziciel uda). W zliofilizowanym materiale biologicznym oznaczono zawartość selenu. Podane jagniętom $\mathrm{w}$ mieszankach treściwych zarówno nieorganiczne (selenin sodu), jak i organiczne (drożdże-Se) formy połączeń selenu zwiększyły zawartość tego pierwiastka w tkankach miękkich jagniąt. Najwięcej selenu znajdowało się w wątrobie i nerkach, odpowiednio 4.65 i 4.90 oraz 2.10 i $2.30 \mathrm{mg} \mathrm{kg}^{-1}$ świeżej tkanki jagniąt otrzymujących w paszy selenin sodu i drożdże-Se w ilości $0.2 \mathrm{mg} \mathrm{Se} \mathrm{kg}^{-1} \mathrm{~s}$ s.m. paszy (gr. II i IV). Stosowane w paszy jagniąt zwiazki selenu wyraźnie $(P \leq 0.01)$ zwiększyły aktywności GSH-Px we krwi owiec, zwłaszcza u zwierząt, które w mieszance otrzymywały drożdże wzbogacone $\mathrm{w}$ selen. U owiec otrzymujących w paszy drożdże-Se w ilości $0.2 \mathrm{mg} \mathrm{Se} \mathrm{kg}^{-1} \mathrm{~s} . \mathrm{m}$. paszy (grupa IV) wykazano wyższą o $129.71 \mathrm{U} \mathrm{gHb}^{-1}$ aktywność peroksydazy glutationowej, a u zwierząt, którym w paszy podawano drożdże-Se w ilości $0.1 \mathrm{mg} \mathrm{Se} \mathrm{kg}^{-1} \mathrm{~s}$.m. paszy lub selenin sodu, aktywność tego enzymu we krwi była wyższa odpowiednio o 86.33 i $86.35 \mathrm{U} \mathrm{gHb}^{-1}$ w porównaniu z grupa kontrolna. Zastosowanie $\mathrm{w}$ dawkach dla jagniąt dodatku Se, zarówno $\mathrm{w}$ formie seleninu, jak i wzbogacanych drożdży, spowodowało wzrost jego zawartości w tkankach miękkich oraz wzrost aktywności peroksydazy glutationowej w porównaniu ze zwierzętami z grupy kontrolnej. Większy wpływ na dostępność Se miał jego poziom w dawce niż stosowana forma.
\end{abstract}

Słowa kluczowe: biodostępność, selen, kumulacja w tkankach, peroksydaza glutationowa. 


\section{INTRODUCTION}

Proper growth and functions of plants and animals require basic nutrients as well as mineral components, including trace elements. Bioavailability of minerals depends on species of animals, their physiological condition, age and body mass, as well as the type and amount of feed given to animals; what matters too is the chemical form of minerals in animal feeds (KIRCHGESSNer et al. 1993, Underwood, SutTLE 1999). Inorganic forms of minerals are poorly absorbed by animals. Minerals are passively absorbed in the small intestine by diffusion of ions, which are only partly utilized by animals while their unused excess is excreted to the environment (KINAL et al. 1994, Rojas et al. 1995, JohAnson, Velasqez 1995). In contrast, the active transport of organically bounded trace elements, by the pathway of transporting complexing groups such as amino acids, polypeptides, polysaccharides and organic acid residues, results in better absorption of organically bounded trace elements than inorganic ones. The amount of minerals that are absorbed, assimilated and used for physiological functions of an organism and stored is referred to as "the bioavailability" (AMMERMAN et al. 1998). As a measure of bioavailability of minerals, their absorption in animal organisms is taken. However, this process is reflected better by the accumulation of minerals in target tissues, or the activity of enzymes whose action is related to the supply of minerals (Ammerman 1995, Miles, Henry 2000).

Selenium strongly affects the growth, reproduction as well as specific and non-specific immunity of both animals and humans (ARTHUR et al 2003). The physiological importance of selenium for living organisms relies on its strong antioxidative activity. Selenium protects animals and people from oxidative stress, which conduces tumours and heart diseases (GRELA, SEMBRATOWICZ 1997). The preventive role of selenium in the origin and growth of some tumours in humans has been emphasized for many years now (Micke et al. 2005).

The aim of the present study has been to determine bioavailability of different chemical forms of selenium. To achieve this target, it was crucial to consider levels of selenium in rations given to growing lambs. The study was made on the basis of selenium accumulation in selected tissues as well as the activity of blood gluthatione peroxidase (GSH-Px).

\section{MATERIAL AND METHOD}

The experimental material consisted of 48 lambs, a crossbreed of Polish Merino x Romanowski x Charolaise, aged $c a 10$ weeks and of average body weight of 20 kilos, which were randomly divided into 4 experimental groups (12 animals per group). The animals were kept collectively (group-pen) on 
deep straw, given an unlimited access to water and fed concentrated feed in the amount of 1.0-1.2 $\mathrm{kg}^{-1} \mathrm{day}^{-1} \mathrm{head}^{-1}$ and some hay rationed according to the body mass and feed uptake. The content of basic nutrients as well as minerals in the feeds covered the animals' requirement according to the NRC system (2001). Feeding groups were diversified with respect to the level and chemical form of selenium in the fodder mixture given to the lambs. In group I, the control, animals received mixtures without selenium supplement. In experimental group II selenium was given to animals as sodium selenite in the amount $0.2 \mathrm{mg}$ Se kg-1 of d.m., and in groups II and III selenium was given as sodium enriched yeast in the amounts 0.1 and $0.2 \mathrm{mg} \mathrm{Se} \mathrm{kg}{ }^{-1}$ of d.m., respectively. At the end of the experiment, blood samples were taken from all the animals whose average body was about $35 \mathrm{~kg}$. In addition, 8 lambs from each group were chosen and killed. Glutathione peroxidase activity was determined in heparinized blood samples using a Randox kit. Soft tissue samples were taken from the killed animals, such as: liver, kidney, brain and adductor femoris muscle. The tissues were lyophilized and the content of selenium was determined (AOAC, 2005). Both, the content of selenium in tissues and glutathione peroxidase activity in blood were used as indicators of the bioavailability of selenium to lambs. All the data were analyzed statistically applying two-factor variance analysis and Duncan's multiple range test with an aid of STATISTICA 7/Stat Lic.

\section{RESULTS AND DISCUSSION}

The data pertaining to the selenium concentration in selected tissues are presented in Table 1. Inorganic (sodium selenite) and organic (Se-yeast) forms of selenium added to feed mixtures for lambs had a positive influence on the concentration of this element in tissues. The highest level of selenium occurred in the liver and kidneys $(P \leq 0.01)$, where it reached 4.65 and 4.90 and 2.10 and $2.30 \mathrm{mg}$ of $\mathrm{Se} \mathrm{kg}^{-1}$ fresh tissue, respectively for the animals which received sodium selenite and Se-yeast in the amount $0.2 \mathrm{mg}$ Se kg-1 of d.m. (groups II and IV). In tissues of these lambs, the level of selenium was higher than in tissues of animals from the remaining groups (Table 1). Besides, in groups Ii and IV the element was also found in the brain and adductor femoris muscle. The lowest amount of selenium was determined in soft tissues of the animals which received Se-yeast in the amount $0.1 \mathrm{mg} \mathrm{Se} \mathrm{kg}{ }^{-1}$ of d.m. in the feed mixture. It was lower than in tissues of animals which received sodium selenite and Se-yeast in the amount $0.2 \mathrm{mg} \mathrm{kg}^{-1}$ of d.m. (groups II and IV). YEH et al. (1997) also reported the highest level of selenium in all examined tissues of animals fed a diet with sodium selenite $\left(0.3 \mathrm{mg}\right.$ Se $\mathrm{kg}^{-1}$ of feed), higher than in tissues of lambs from the negative group, without selenium supplementation. The high- 
Table 1

The content of selenium in some soft tissues of lambs (in $\mathrm{mg} \mathrm{kg}^{-1}$ fresh matter)

\begin{tabular}{|c|c|c|c|c|c|}
\hline \multirow{2}{*}{\multicolumn{2}{|c|}{}} & \multicolumn{4}{|c|}{ Feeding groups } \\
\cline { 2 - 5 } \multicolumn{2}{|c|}{ Item } & $\begin{array}{c}\text { I } \\
\text { control }\end{array}$ & $\begin{array}{c}\text { II } \\
\text { sodium selenite } \\
\left(0.2 \mathrm{mg} \mathrm{kg}^{-1} \mathrm{~d} . \mathrm{m} .\right)\end{array}$ & $\begin{array}{c}\text { III } \\
\text { Se-yeast } \\
\left(0.1 \mathrm{mg} \mathrm{kg}^{-1} \mathrm{~d} . \mathrm{m} .\right)\end{array}$ & $\begin{array}{c}\text { IV } \\
\text { Se-yeast } \\
\left(0.2 \mathrm{mg} \mathrm{kg}^{-1} \mathrm{~d} . \mathrm{m}^{2}\right)\end{array}$ \\
\hline Liver & $\bar{x}$ & 3.62 & 4.65 & 3.90 & 4.90 \\
\hline Kidney & $\bar{x}$ & $1.59^{A}$ & $2.10^{A B}$ & $1.86^{A B}$ & $2.30^{B}$ \\
\hline $\begin{array}{c}\text { Adductor femoris } \\
\text { muscle }\end{array}$ & $\bar{x}$ & $0.044^{A}$ & $0.13 \mathrm{~B}$ & $0.048^{A}$ & $0.14^{B}$ \\
\hline Brain & $\bar{x}$ & 0.033 & 0.045 & 0.040 & 0.046 \\
\hline
\end{tabular}

A, B - high significant differences $(P \leq 0.01)$

est level of selenium was in the liver, kidneys, brain and muscles in the order: $5.02 ; 3.29 ; 0.43$ and $0.26 \mathrm{mg} \mathrm{kg}^{-1} \mathrm{~d} . \mathrm{m}$. of tissue. After conversion to fresh matter, these results correspond to our data (Table 1). Increased levels of selenium in selected tissues after selenium supplementation were reported also by RichaRds and LOVEDAY (2003), who added selenium in the amount $0.3 \mathrm{mg} \mathrm{Se} \mathrm{kg}{ }^{-1} \mathrm{~d} . \mathrm{m}$. as Selplex to rations given to calves.

The data concerning the activity of glutathione peroxidase (GSH-Px) in blood are presented in Table 2. Selenium compounds added to feed mixtures for lambs significantly $(P \leq 0.01)$ increased bloods GSH-Px activity, especially in blood samples form animals which received yeast enriched with selenium. Lambs which received Se-yeast in the amount $0.2 \mathrm{mg} \mathrm{Se} \mathrm{kg-1} \mathrm{d.m.} \mathrm{of}$ feed (group IV) had $129.71 \mathrm{U} \mathrm{gHb}^{-1}$ higher GSH-Px activity than the control animals. An analogous increase, versus the control, reached $86.33 \mathrm{U} \mathrm{gHb}^{-1}$ for animals which received Se-yeast in the amount $0.1 \mathrm{mg} \mathrm{Se} \mathrm{kg-1} \mathrm{d.m.} \mathrm{in}$ feed and $86.35 \mathrm{U} \mathrm{gHb}^{-1}$ in the case of lambs which were given sodium selenite as a fodder supplement (Table 2). BALDI•AROwA et al. (2005), who gave lambs fodder enriched with selenium yeast in the amount $0.3 \mathrm{mg} \mathrm{Se} \mathrm{kg}{ }^{-1}$ d.m., also observed increased GSH-Px blood activity. On the other hand,

Lambs blood glutathione peroidase (GSH-Px) activity $\left(\mathrm{U} \mathrm{gHb}^{-1}\right)$

\begin{tabular}{|c|c|c|c|c|}
\hline \multirow{2}{*}{ Item } & \multicolumn{3}{|c|}{ Feeding groups } \\
\cline { 2 - 5 } & $\begin{array}{c}\text { I } \\
\text { control }\end{array}$ & $\begin{array}{c}\text { II } \\
\text { sodium selenite } \\
\left(0.2 \mathrm{mg} \mathrm{kg}^{-1} \mathrm{~d} . \mathrm{m} .\right)\end{array}$ & $\begin{array}{c}\text { III } \\
\text { Se-yeast } \\
\left(0.1 \mathrm{mg} \mathrm{kg}^{-1} \mathrm{~d} . \mathrm{m} .\right)\end{array}$ & $\begin{array}{c}\text { IV } \\
\text { Se-yeast } \\
\left(0.2 \mathrm{mg} \mathrm{kg}^{-1} \mathrm{~d} . \mathrm{m} .\right)\end{array}$ \\
\hline $\begin{array}{c}\text { Activity } \\
\text { of } \\
\text { GSH-Px (U gHb-1) }\end{array}$ & $521.57^{A}$ & $604.58^{B}$ & $614.5^{B}$ & $641.43^{B}$ \\
\hline
\end{tabular}

A, B - high significant differences $(P \leq 0.01)$ 
there was no increase in GSH-Px in the blood of animals which received sodium selenite in feed mixture. However, JoHANsson et al. (1990), who supplemented lambs' feed with selenium enriched yeast and sodium selenite in the amount of $0.1 \mathrm{mg}$ Se day $^{-1} \mathrm{head}^{-1}$, did not find any significant increase in the GSH-Px activity in the animals' blood. Likewise, Podoll et al. (1992), who supplemented diets of lambs with inorganic selenium forms, sodium selenite and selenate ( $0.3 \mathrm{mg}$ Se $\mathrm{kg}^{-1}$ of mixture), did not notice any increase in the GSH-Px blood activity.

\section{CONCLUSION}

1. Inorganic and organic selenium forms used as feed supplements are an effective way of increasing the concentration of this element in soft tissues and enhance glutathione peroxidase activity.

2. The level of selenium supplement rather than its form was more important for utilization of this nutrient by lambs.

3. Selenium supplements added to lambs' rations, which increase concentration of Se in meat, could be useful in production of nutraceutics.

\section{REFERENCES}

Ammermann C.B. 1995. Methods for Estimation of Mineral Bioavailability. In: Bioavailability of nutrients for animals. Ammermann C.B., BAKer H.D., Lewis A.J. (Ed.). Academic Press, NY, 83-94.

Ammermann C.B., Henry P.R., Miles R.D. 1998. Supplemental organically-bound mineral compounds in livestock nutrition. In: Recent Advances in Animal Nutrition. P.C. GARNSWORTHY and Wiseman (Ed), Nottingham Unversity Press, 67-91

AOAC. 2005. Official Methods of Analysis of the Association on Official Analytical Chemists. $17^{\text {th }}$ Ed Kenneth, Helrich, Arlington, USA.

Baldi•Árová K., GreŠÁková L., FaIX Š., MELlen M., Leng L. 2005. Antioxidant status of lambs fed on diets supplemented with selenite or Se-yeast. J. Anim. Feed Sci., 14: 245-253.

Arthur J.R., Mckenzie R.C., Beckett G.J. 2003. Selenium in the immune system. J. Nutr., 133: 1457-1459.

Grela E., Sembratowicz I. 1997. Selen w żywieniu zwierzq̨t. Post. Nauk. Rol., 1: 97-106.

KInAL S., ŁuCZAK W., PREŚ J. 1994. Ocena chemiczna różnych dolomitów i kredy oraz ich wptyw na wykorzystanie $\mathrm{Ca}, \mathrm{P}, \mathrm{Mg}, \mathrm{Zn}, \mathrm{Cu}$ i składników organicznych $w$ żywieniu owiec. Rocz. Nauk. Zoot., 21 (1-2): 181-194.

Kirchgessner M., Windish W., Wegand E. 1993. True bioavailability of zinc and manganese by isotope dilution technique. Bioavailability 93, nutritional, chemical and food processing implications of nutrient availability. Ettingen 9-12.05.1993, Proceed J., 213-223.

Micke O., Büntzel J., Bruns F., Schüller P., Glatzel M., Schönekaes K.G., kisters K., Mücke R. 2005. Selenium in oncology-current status and future perspectives. J. Elementol., 10 (1): 201-210. 
Miles R.D., Henry P.R. 2000. Relative trace mineral bioavilability. Ciencia Animal Brasiliera, 1(2): 73-93

Nutrients Requirements of Animals. 2001. National Academy of Sciences-National Research Council, Washington, D.C.

Podoll K.L., Bernard J.B., Ullrey D.E., Debar S.R., Ku P.K., Magee W.T. 1992. Dietary selenate versus selenite for cattle, sheep and horses. J. Anim. Sci., 70: 1965-1970.

RICHARDS C.J., LovEDAY H.D. 2003. Redefining selenium nutrition using organic selenium (Sel-Plex®): Defining maximal acceptable tissue residues in beef. Nutritional biotechnology in the feed and food industries. Proc. of Alltech's $19^{\text {th }}$ Annual Symp., Ed. by T.P. LYONS and K.A. JACQUES, 211-220.

Rojas L.X., Mcdowell L.R., Cousins R.J., Martin F.G., Wilkinson N.S., Johanson A.B., Velasqez J.B. 1995. Relative bioavability of two organic and two inorganic zinc sources fed to sheep. J. Anim. Sci., 73: 1202-1207.

Johansson E., Jacobsson S.O., Luthman J., Lindh U. 1990. The biological response of selenium in individual erythrocytes and GSH-Px in lambs fed sodium selenite or selenium yeast. J. Vet.Med. Assoc., 37: 463-470.

Johanson A.B., VELASQEz J.B. 1995. Relative bioavability of two organic and two inorganic zinc sources fed to sheep. J. Anim. Sci., 73: 1202-1207.

Underwood E.J., Suttle N.F. 1999. Mineral nutrition of livestock. Selenium. $3^{\text {rd }}$ editio. CAB International Publishing, New York, 421-475.

Yeh J.Y., Gu Q.P., Beilstein M.A., Forsberg N.E., Whagner P.D. 1997. Selenium influences tissue levels of selenoprotein $w$ in sheep. J. Nutr., 127 (3): 394-402. 
